園学雑. (J. Japan. Soc. Hort. Sci.) $65(4)$ ：713-722. 1997.

\title{
トウガラシの品種間雑種の果実の収量, アスコルビン酸および カプサイシノイド含量
}

\author{
曹萬鎬・山本昌豊・松原幸子・村上賢治 \\ 岡山大学㟽学部, 岡山市津島 700
}

\begin{abstract}
Fruit Yield, and Ascorbic Acid and Capsaicinoid Contents in the Fruit of Intervarietal Hybrids of Capsicum annurm L.
\end{abstract}

Man-Hyun Jo, Masatoyo Yamamoto, Sachiko Matsubara and Kenji Murakami

Faculty of Agriculture, Okayama University, Tsushima, Okayama 700

\begin{abstract}
Summary
The fruit yield and ascorbic acid (AscA) and capsaicinoid contents of $F_{1}$ hybrids between Capsicum annum L. 'California Wonder', four Japanese native cultivars, and five Korean $\mathrm{F}_{1}$ cultivars were evaluated and the results compared with parental cultivars.

The yields of $F_{1}$ hybrids between the Japanese cultivars were higher than those of the parental cultivars, especially those of 'California Wonder'.

AscA content in the fruit flesh increased for 4 to 5 weeks, but decreased at 8 weeks after flowering. In all cultivars, AscA content, which differed little, gradually increased until September, and decreased in October. The AscA content in the fruit flesh was three times that of the placenta.

The capsaicinoid content was higher in the placenta than in the flesh of fruit. Fruits of 5 cultivars including 'Yatsufusa' were most pungent, with capasaicinoid content exceed. ing $1000 \mathrm{mg} / 100 \mathrm{gDW}$, whereas 'California Wonder' and 'Fushimi Amanaga' contained trace amounts. The content of capsaicinoids in $F_{1}$ hybrids varied with reciprocal crossing. Red mature fruits had lower capsaicinoid contents than did green immature ones. The capsaicinoid contents also varied with the stage of developement of the fruit, being low in the first week after flowering, rapidly increasing in the 2 nd to $3 \mathrm{rd}$ week, reaching a peak at the 5 th week, and declining thereafter.
\end{abstract}

\section{緒言}

トウガラシは，香辛野莱として世界中の食生活に久 かせない重要な園芸作物の一つである．Capsicum 属 にはいくつかの種があるが，栽培されているトウガラ シはほとんどがCapsicum annuum L.である.この種 の原産地はメキシコを中心とする中米で，現在世界で 広く栽培されている。トウガラシには, 辛味品種と猄 味のない品種があり，種々の辛味程度のものがある. 辛味品種の果実の品質の最も重要な要素は，カプサイ シノイド (辛味成分) 含量である，朴・高橋 (1980) は，辛さが異なる 3 品種とそれらの $F_{1}$ 雑種を供試し， 果実の発育に伴う果実中のカプサイシノイド含量の変

平成 8 年 4 月 17 日 受付. 平成 8 年 6 月 28 日 受理.
化をモリブデンブルー比色法で分析した結果, 開花後 4ー5 週間目まで急上昇したことを報告している。ま た，矢澤ら（1989）は, Capsicum annuum L.の栽培品 種とC. chinense Jacq. との $F_{1}$ 雑種，掞よびC. annum の品種間交雑種の果実中のカプサイシノイド含量を薄 層クロマトグラフィーで定是し，辛味の遺伝様式が親 品種により異なることを報告している。しかし，果実 の発育に伴うカプサイシノイド含获の変化や辛味の遭 伝については，まだ十分に明らかにされていない。近 年，高速液体クロマトグラフィー（HPLC）の利用に より，微星の試料でも迅速にカプサイシノイドの定星 ができるようになった（Attuquayefio・Buckle, 1987； Collins et. al, 1995). 本研究では，この技術を利用し て果奏の発育に伴うカプサイシノイド含望の変化や, 
交雑種のカプサイシノイド含量について検討を行った，

トウガラシの果実品質のもう一つの重要な要素とし て、アスコルビン酸（ビタミンC）含量がある。トウ ガラシでは，辛味のない品種を用いたアスコルビン酸 含最についてのいくつかの研究が報告されており，栽 培環境の影響が調べられている（菅原，1943；篠原ら， 1980 ; 今堀・茶珍, 1995). しかし，アスコルビン酸 含量の品種間差異, 果実の発育に伴う変化, 季節的变 化，交雑による遺伝については，十分に調べられてい ない.

以上のように本研究では, 高収量・高品質のトゥガ ラシ新品種を育成するための基礎的知見を得る目的で, 日本の辛味のない品種と辛味品種拈よび韓国の $\mathrm{F}_{1}$ 品 種を供試し, 品種間雑種の収量, 果実の形態的特性, 果実のアスコルビン酸およびカプサイシノイド含量を 調査した：そしてトウガラシ果実のアスコルビン酸挹 よびカプサイシノイド含量に影響を及ぼす要因につい て考察した。

\section{1.交雑親と雑種の収量}

Capsicum annuum L. の固定種 ‘カリフォルニア・ワ ンダー・('CW'とする) (タカヤマシード, 京都), 日 本の在来種である ‘伏見甘長”（夕キイ種苗，京都）, 'ししとう' (東北種苗, 栃木), ‘八房' (夕キイ種苗, 京都)，“鹰の爪’ (タカヤマシード, 京都), さらに 1993 年に以上の 5 品種を交雑して得られた $\mathrm{F}_{1}$ 雑種 のうち 12 系統 (第 1 表参照)，韓国の $F_{1}$ 品種の 'Cheongyang' (中央種苗, 韓国·天安), 'Sinhong' (興宸種苗, 韓国・ソウル), ‘Geoseong’(ソウル種苗, 韓国・ソウル), 'Seoulsilggwaripud’(ソウル種苗, 韓 国・ソウル), ‘Ggwaripud'(興農種苗, 韓国・ソウ ル）の計 22 種類を供試した。各品種の種子を, 岡山 大学宸学部の無加温ガラス温室でバーミキュライトを 入れた播種箱に 1995 年 4 月 5 日播種した。植物体の 本葉が出る直前の 4 月 26 日に, 培養土を入れた直径 $9 \mathrm{~cm}$ のビニルポットに鉢上げした。引き続き同じガ ラス温室で充苗し, 植物体の本葉が8 10枚展開した 5 月 25 日に本國（露地）に定植した。

栽植密度は, 即幅 $120 \mathrm{~cm}$, 株間 $40 \mathrm{~cm}$ の一条植之 とした，植え付け株数は 1 品種当たり 4 株とした。本 围の施肥量は, $10 \mathrm{a}$ 当たり登素 $24 \mathrm{~kg}$, リン酸 $20 \mathrm{~kg}$, カリ $23 \mathrm{~kg}$ とし，窒素のうち約 $1 / 3$ を元肥，残りを 6 月 7 日，7月 26 日と 9 月 11 日に追肥で施用した。こ れらの植物体は 1995 年 11 月まで栽培した。1995 年 7
月 26 日から 8 月 31 日まで1系統あたり 2 株から着果 した未熟果（開花的 3 4 週間後）を順次収雀して直 ちに生体重を測定し，期間内の収秘した果実の重さの 合計値をその系統の収量とした．9月以降は台風によ る植物体の被害が考えられるため, 調査は 8 月 31 日 で打ち切った。

\section{2. 果実中のアスコルビン酸含量}

前述した 22 種類の植物の開花後約 3 4 週間の未熟 果と, 開花約 6 7 週間後の果実 (赤熟果) を収穫し, 収穫後直ちにアスコルビン酸含量の测定に供した。未 熟果では 7，8，9，10月に収雀した果実を, 赤熟果で は9，10月に収穫した果実を用いた，また，果実の発 䏍に伴うアスコルビン酸の経時的変化を調べるため, 'ししとう', '應の爪', 'Cheongyang', 'Sinhong'の 4 品 種を用い，1995 年 7 月 18 日から 1 週間㧍きに 8 週間 目まで当日開花した花にラベルを付け，9月12 日ラ ベルのついている果実を一斉に収秒し測定した。

アスコルビン酸の定量には, 還元型のアスコルビン 酸を測定するインドフェノール法（南出，1981）によ り行った，収穫直後の果実の果皮の $5 \mathrm{~g} \quad(1 \sim 10$ 果実 分）を乳鉢に取り，5\%メタリン酸溶液 $20 \mathrm{ml}$ を加え 手早く磨砝した。これに純水 $25 \mathrm{ml}$ を加之, メタリン

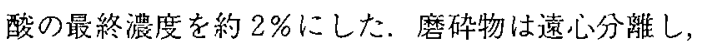
上澄みを抽出液とした。この抽出液を $2 \%$ メリン酸 溶液で 20 倍希釈したものをビューレット（容量 5 ml）に取り，あらかじめ湄度を検定して㧍いたイン ドフェノール液を用いて滴定した．各処理区につき異

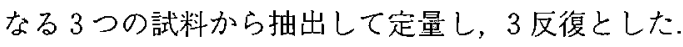

また，8月3日から6日にかけて収穫した果実の胎 座からアスコルビン酸を同様の方法で抽出・定量した。 この定是は名処理区につき 1 試料からの抽出液につい て行った。

\section{3. 果実中のカプサイシノイドの含量}

供試材料は前述した 22 種類のうち韓国の $F_{1}$ 品種 'Seoulsilggwaripud' と 'Ggwaripud'を除く20 種類を用 い, 1995 年 8 月から 9 月にかけて収稪した未熟果と 赤熟果を供試した。また，果実の発育に伴うカプサイ シノイド含量の変化を調べるため，“ししとう’，鹰の 爪’㧍よび'Cheongyang'の3 品種を供試し, 1995 年 7 月 18 日から 1 週間㧍きに 8 週間目まで当日開花した 花にラベルを付け，9月12 日にラベルのついた果寒 を一斉に収穫したここれらの果実は収穫後，果皮と胎 座に分け，細切後風乾した。十分に乾燥した試料を 1 処理区分ずつまとめて日立コーヒーミル（CM-602) 
または乳鉢で磨研して細かい粉末にし，サンプル管に 入れシリカゲル入りのデシケーター内で保存した．こ の粉末試料 $100 \mathrm{mg}$ ，辛味品種はメ夕ノール $100 \mathrm{ml}$ に，辛味のない品種では同量を $1 \mathrm{ml}$ に䀣濁して試験 管に入れ，超音波洗浄器 (Yamoto 5210) で2分間超 音波処理し，カプサイシノイドを抽出した．抽出液は フィルター (DISMICl3HP, $0.20 \mu \mathrm{m} ;$ TOYO Roshi Inc.) を用いてろ過した。カプサイシノイドの定量は, HPLC（島津，LC-10AD）を用い，以下に述べる方法 (島津製作所，1994，私信）で行った．抽出液 $25 \mu \mathrm{l}$ を $4.6 \mathrm{~mm} \times 150 \mathrm{~mm}$ の STR ODS-II カラム（島津）に 注入し, カラム温度 $40^{\circ} \mathrm{C}$, 移動相はアセトニトリル 純水 $(45: 55, v / v ， 0.05 \%$ リ酸), 流速 $1 \mathrm{ml} / \mathrm{min}$., 吸光度 $280 \mathrm{~nm}$ でカプサイシノイドを分離・分析した。 カプサイシノイドの定量は，カプサイシン（東京化成 工業) の標準溶夜を基準として行った，以上の測定は 1 処理区につき 1 回行った.

\section{結果 \\ 1. 交雑親と雑種の収量}

1995 年 7 月 26 日から 8 月 31 日までの未熟果の収 量第1表に示した。‘カリフォルニア・ワンダー (CW)'，“伏見甘長”が株当たり $700 \mathrm{~g}$ 以上， ‘しとう’

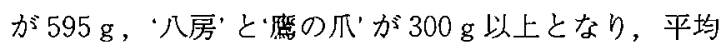
$560 \mathrm{~g}$ であった。 それに対して F 雑種は No.6の 1270 $\mathrm{g}$ からNo.8の $561 \mathrm{~g}$ までの幅があったが，平均 $863 \mathrm{~g}$ で，いずれも親品種より多収であった，最も収量が多 かったのは $\mathrm{F}_{1}$ 雑種の No.6 ('CW'× '伏見甘長') で,

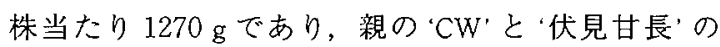
1.6〜1.8倍であった， $F_{1}$ 雑種の No.7，13 も，株当 たり $1 \mathrm{~kg}$ を超える高収量であった。これらはいずれ も ‘CW'が片親である。韓国の $\mathrm{F}_{1}$ 品種は‘Cheon. gyang' の $928 \mathrm{~g}$ から 'Sinhong'の $437 \mathrm{~g}$ まで幅があり， 平均は $799 \mathrm{~g}$ であった。

\section{2. 果実中のアスコルビン酸含量}

未熟果のアスコルビン酸含量については第 2 表に, 赤熟果のアスコルビン酸含量について第 3 表に示した.

Table 1. Yield of immature fruits for 37 days from July 26 to August 31. 1995.

\begin{tabular}{|c|c|c|c|c|}
\hline Group & No. Cultivar & $\begin{array}{l}\text { Mean fruit } \\
\text { yield }(\mathrm{g} / \text { plant })\end{array}$ & $\begin{array}{l}\text { No. of fruits } \\
\text { per plant }\end{array}$ & $\begin{array}{l}\text { Fresh weight } \\
\text { per fruit (g) }\end{array}$ \\
\hline Bell pepper & 1.California Wonder & 785.6 & 32.5 & 24.0 \\
\hline \multirow[t]{6}{*}{ Japanese cultivar } & 2. Fushimi Amanaga & 705.4 & 158.5 & 4.4 \\
\hline & 3. Shishitou & 595.0 & 183.0 & 3.2 \\
\hline & 4. Yatsufusa & 373.0 & 277.0 & 1.3 \\
\hline & 5. Taka no Tsume & 340.0 & 264.5 & 1.3 \\
\hline & Mean $\pm S D$ & $559.8 \pm 197.9$ & $183.1 \pm 98.4$ & $6.8 \pm 9.7$ \\
\hline & 우 $\hat{3}$ & & & \\
\hline \multirow[t]{13}{*}{$F_{1}$ hybrid } & $6.1 \times 2$ & 1270.3 & 81.0 & 15.7 \\
\hline & $7.1 \times 3$ & 1090.6 & 108.5 & 10.1 \\
\hline & $8.1 \times 4$ & 561.6 & 100.5 & 5.7 \\
\hline & $9.1 \times 5$ & 847.6 & 193.5 & 4.4 \\
\hline & $10.2 \times 1$ & 749.3 & 70.5 & 10.6 \\
\hline & $11.2 \times 3$ & 918.9 & 248.0 & 3.7 \\
\hline & 12. $2 \times 4$ & 643.6 & 281.0 & 2.3 \\
\hline & $13.3 \times 1$ & 1169.5 & 103.0 & 11.3 \\
\hline & $14.3 \times 2$ & 890.5 & 206.0 & 4.3 \\
\hline & $15.4 \times 1$ & 662.0 & 134.5 & 4.9 \\
\hline & $16.4 \times 2$ & 716.4 & 297.5 & 2.4 \\
\hline & $17.5 \times 1$ & 836.1 & 137.0 & 6.1 \\
\hline & Mean $\pm S D$ & $863.0 \pm 219.6$ & $163.4 \pm 79.4$ & $6.8 \pm 4.2$ \\
\hline \multirow[t]{6}{*}{ Korean $F_{l}$ cultivar } & 18. Cheongyang & 928.3 & 245.0 & 3.8 \\
\hline & 19. Sinhong & 493.8 & 148.0 & 3.4 \\
\hline & 20. Geoseong & 995.8 & 146.5 & 6.8 \\
\hline & 21.Seoulsilggwaripud & 726.5 & 230.5 & 3.1 \\
\hline & 22. Ggwaripud & 851.2 & 284.0 & 3.0 \\
\hline & Mean $\pm S D$ & $799.1 \pm 197.9$ & $210.8 \pm 61.2$ & $4.0 \pm 1.6$ \\
\hline
\end{tabular}


Table 2. Content of ascorbic acid in fruit flesh and placenta of immature fruits from July 26 to October 12.1995.

\begin{tabular}{|c|c|c|c|c|c|c|}
\hline \multirow{3}{*}{ Group } & \multirow{3}{*}{ No. Cultivar } & \multirow{2}{*}{ 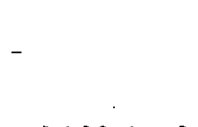 } & \multicolumn{3}{|c|}{ Content of ascorbic acid (mg/100g FW) } & \multirow[b]{2}{*}{ Placenta } \\
\hline & & & \multicolumn{2}{|c|}{ Flesh } & \multirow[b]{2}{*}{ Oct.10-12 } & \\
\hline & & Jul.26-Aug. 3 & Aug. $20-29$ & Sep.21-24 & & Aug. $3-6$ \\
\hline Bell pepper & 1. California Wonder & $99.9 \pm 1.6^{2}$ & $177.8 \pm 18.8$ & $207.6 \pm 31.1$ & $182.2 \pm 35.1$ & 49.9 \\
\hline \multirow[t]{5}{*}{ Japanese cultivar } & 2.Fushimi Amanaga & $151.2 \pm 22.4$ & $239.8 \pm 25.8$ & $257.9 \pm 21.9$ & $213.4 \pm 31.0$ & 41.9 \\
\hline & 3.Shishitou & $123.3 \pm 19.4$ & $176.8 \pm 9.1$ & $259.1 \pm 26.4$ & $153.5 \pm 35.7$ & 45.2 \\
\hline & 4. Yatsufusa & $117.5 \pm 4.2$ & $176.4 \pm 15.0$ & $253.2 \pm 32.2$ & $222.4 \pm 23.2$ & 45.4 \\
\hline & 5. Taka no Tsume & $102.3 \pm 35.8$ & $135.3 \pm 16.4$ & $255.9 \pm 25.9$ & $172.2 \pm 67.5$ & 38.1 \\
\hline & $\begin{array}{r}\text { Mean } \\
\text { 우 } \hat{\delta}\end{array}$ & 118.8 & 181.2 & 246.7 & 188.7 & 44.1 \\
\hline \multirow[t]{13}{*}{$F_{1}$ hybrid } & $6.1 \times 2$ & $123.5 \pm 27.3$ & $243.0 \pm 48.1$ & $298.4 \pm 26.6$ & $185.2 \pm 43.7$ & 38.9 \\
\hline & $7.1 \times 3$ & $134.8 \pm 10.4$ & $149.8 \pm 17.9$ & $230.6 \pm 23.6$ & $191.6 \pm 45.3$ & 37.2 \\
\hline & $8.1 \times 4$ & $163.4 \pm 2.4$ & $201.5 \pm 31.4$ & $254.7 \pm 25.3$ & $199.2 \pm 48.4$ & 35.7 \\
\hline & $9.1 \times 5$ & $140.2 \pm 7.2$ & $185.1 \pm 31.2$ & $282.8 \pm 19.6$ & $176.7 \pm 43.7$ & 42.4 \\
\hline & $10.2 \times 1$ & $132.0 \pm 16.6$ & $159.9 \pm 35.0$ & $234.5 \pm 11.3$ & $183.2 \pm 22.3$ & 32.1 \\
\hline & $11.2 \times 3$ & $135.5 \pm 38.1$ & $185.6 \pm 21.7$ & $187.7 \pm 50.6$ & $221.6 \pm 52.5$ & 38.7 \\
\hline & $12,2 \times 4$ & $142.3 \pm 8.2$ & $225.0 \pm 20.6$ & $276.5 \pm 21.5$ & $236.9 \pm 9.7$ & 37.6 \\
\hline & $13.3 \times 1$ & $128.6 \pm 27.9$ & $165.5 \pm 16.3$ & $202.9 \pm 12.3$ & $178.4 \pm 35.2$ & 35.5 \\
\hline & $14.3 \times 2$ & $147.2 \pm 21.0$ & $243.5 \pm 31.6$ & $212.3 \pm 35.4$ & $205.3 \pm 24.6$ & 56.1 \\
\hline & $15.4 \times 1$ & $130.2 \pm 1.9$ & $183.9 \pm 31.5$ & $246.9 \pm 56.6$ & $229.0 \pm 32.8$ & 42.9 \\
\hline & $16.4 \times 2$ & $145.9 \pm 15.5$ & $259.9 \pm 7.6$ & $318.8 \pm 17.2$ & $243.3 \pm 16.1$ & 41.1 \\
\hline & $17.5 \times 1$ & $125.0 \pm 16.0$ & $210.0 \pm 41.1$ & $266.0 \pm 49.2$ & $243.7 \pm 30.1$ & 42.3 \\
\hline & Mean & 137.4 & 201.1 & 251.0 & 207.8 & 40.0 \\
\hline \multirow[t]{6}{*}{ Korean $F_{1}$ cultivar } & 18. Cheongyang & $143.0 \pm 25.4$ & $173 . \dot{4} \pm 19.8$ & $252.4 \pm 35.7$ & $205.1 \pm 30.5$ & 43.3 \\
\hline & 19. Sinhong & $165.8 \pm 26.4$ & $173.4 \pm 5.0$ & $238.5 \pm 29.6$ & $173.6 \pm 5.6$ & 47.3 \\
\hline & 20. Geoseong & $196.9 \pm 37.7$ & $184.5 \pm 39.4$ & $239.8 \pm 34.4$ & $233.5 \pm 5.8$ & 56.6 \\
\hline & 21. Seoulsilggwaripud & $191.7 \pm 39.1$ & $179.5 \pm 12.2$ & $193.9 \pm 23.5$ & $217.4 \pm 22.1$ & 62.6 \\
\hline & 22. Ggwaripud & $158.9 \pm 29.9$ & $218.1 \pm 34.0$ & $261.8 \pm 37.5$ & $205.6 \pm 16.8$ & 50.0 \\
\hline & Mean & 171.3 & 185.8 & 237.3 & 207.0 & 52.0 \\
\hline Mean of all cultivars & & 140.9 & 193.1 & 246.9 & 203.3 & 43.7 \\
\hline
\end{tabular}

未熟果の果皮のアスコルビン酸含量は，全品種の平均 值で見ると7，8，9，10月がそれぞれ 141，193，247， $203 \mathrm{mg} / 100 \mathrm{gFW}$ となり，9月が最も高濃度であった。 アスコルビン酸含量の品種間差異については，明らか な傾向が見られなかった.

トゥガラシ果実中のカプサイシノイド含量は，後述 のように果皮と胎座で大きな差が見られたので，アス コルビン酸含量についても果皮と胎座を分けて測定し たところ，胎座のアスコルビン酸含量は果皮より低く， 平均して果皮の $1 / 3$ 以下であった（第 2 表).

第 3 表に示した赤熟果のアスコルビン酸含昂を見る と, ‘房’ 以外の全ての品種で未熟果より高濃度であ った.

果実の発育に伴うアスコルビン酸含量の変化につい ては，第1図に示したようにししとうでは，開花後
1 週間目から徐々に増加し，8週間目まで増加し続け た。鷹の爪’では，5週間目以降はあまり増加しなか った. 'Cheongyang'は，開花後 3 週間目まで徐々に増 加したがそ机以降は余り増加しなかった，'Shinhong' は，開花後 4 週間目までは急激に增加したがその後は 緩やかに増加した．以上の結果，開花後8週間目まで アスコルビン酸含盀が増加し続ける品種と，果実が赤 くなるにつれ滅少していく品種が存在した。

\section{3. 果実中のカプサイシノイドの含量}

赤熟果の恳の爪胎座のカプサイシノイドのクロ マトグラムを第 2 図に示した。カプサイシノイドに関 連のある 4 ピークが認められ，それぞれ保持時間の短 い方より， nordihydrocapsaicin (NDHC), capsaicin (C), dihydrocapsaicin (DHC)，4番目のピークは $\mathrm{n}$. vanillyl-n-decanamide（VD）または dihydrocapsaicin 
Table 3. Content of ascorbic acid in fruit flesh of red mature fruits from September 16 to October 9. 1995 .

\begin{tabular}{|c|c|c|c|}
\hline \multirow{2}{*}{ Group } & \multirow{2}{*}{ No. Cultivar } & \multicolumn{2}{|c|}{ Content of ascorbic acid in flesh $(\mathrm{mg} / 100 \mathrm{~g} \mathrm{FW})$} \\
\hline & & Sep.16-20 & Oct.6-9 \\
\hline Bell pepper & 1.California Wonder & $241.0 \pm 15.4^{z}$ & $230.3 \pm 13.5$ \\
\hline \multirow{6}{*}{ Japanese cultivar } & 2.Fushimi Amanaga & $350.4 \pm 47.1$ & $345.3 \pm 25.1$ \\
\hline & 3. Shishitou & $293.8 \pm 16.8$ & $322.3 \pm 23.4$ \\
\hline & 4. Yatsufusa & $222.4 \pm 25.2$ & $225.9 \pm 10.9$ \\
\hline & 5. Taka no Tsume & $265.6 \pm 8.5$ & $256.8 \pm 21.5$ \\
\hline & Mean & 274.6 & 276.1 \\
\hline & 우 $\hat{\delta}$ & & \\
\hline \multirow[t]{13}{*}{$F_{1}$ hybrid } & $6.1 \times 2$ & $333.5 \pm 29.2$ & $254.9 \pm 6.8$ \\
\hline & $7.1 \times 3$ & $262.3 \pm 14.0$ & $291.5 \pm 25.7$ \\
\hline & $8.1 \times 4$ & $330.3 \pm 13.2$ & $327.5 \pm 12.6$ \\
\hline & $9.1 \times 5$ & $298.4 \pm 10.0$ & $300.7 \pm 18.8$ \\
\hline & $10.2 \times 1$ & $251.8 \pm 38.8$ & $260.7 \pm 39.5$ \\
\hline & $11.2 \times 3$ & $265.1 \pm 15.0$ & $329.7 \pm 24.7$ \\
\hline & $12.2 \times 4$ & $308.9 \pm 19.4$ & $323.6 \pm 6.2$ \\
\hline & $13.3 \times 1$ & $281.5 \pm 14.3$ & $287.6 \pm 33.5$ \\
\hline & $14.3 \times 2$ & $324.5 \pm 16.1$ & $357.5 \pm 32.9$ \\
\hline & $15.4 \times 1$ & $360.6 \pm 23.2$ & $375.9 \pm 14.8$ \\
\hline & $16.4 \times 2$ & $385.8 \pm 11.9$ & $406.9 \pm 45.3$ \\
\hline & $17.5 \times 1$ & $294.4 \pm 22.8$ & $342.9 \pm 8.2$ \\
\hline & Mean & 308.1 & 321.6 \\
\hline \multirow[t]{6}{*}{ Korean $F_{1}$ cultivar } & 18. Cheongyang & $288.7 \pm 18.9$ & $298.8 \pm 20.3$ \\
\hline & 19. Sinhong & $291.2 \pm 13.0$ & $258.2 \pm 34.7$ \\
\hline & 20.Geoseong & $319.1 \pm 22.9$ & $387.6 \pm 13.1$ \\
\hline & 21.Seoulsilggwaripud & $326.3 \pm 28.7$ & $290.9 \pm 21.1$ \\
\hline & 22.Ggwaripud & $334.6 \pm 32.0$ & $268.0 \pm 36.2$ \\
\hline & Mean & 312.0 & 300.7 \\
\hline Mean of all cultivars & & 301.4 & 306.5 \\
\hline
\end{tabular}

の異性体と考えられた (Collins ら，1995)．各品種毎 の未熟果と赤熟果について，果皮と胎座別のそれぞれ の含量は第 4 表に示した。Cを DHCが主要な辛昧成 分で，含量が多かった、NDHCとVDは含量が少なく， 特に後者が僅かであった４つの物質の合計の含量は， 未熟果, 赤熟果とも胎座の方が高く，果皮の $10 ４ 00$ 倍近くあった、末熟果の胎座の 4 つの物質の合計カプ サイシノイド含量では，八房'拉よび Cheongyang'が $3000 \mathrm{mg} / 100 \mathrm{gDW}$ 以上で最も辛く, 次いで'Sinhong', “鹰の爪', 'Geoseong', 'CW'と ‘房'の $\mathrm{F}_{1}$ 雑種が 1000 2000 mg/100 gDWであった。ししとう’は 54 $\mathrm{mg} / 100 \mathrm{gDW}$ と八房’などに比べて低濃度であったが， かなりの辛味があった。'CW'はカプサイシノイドは 全くなく，伏見甘長'は非常に低濃度であり，辛味は 全く感じられなかった，辛味のない品種と辛味品種と の $\mathrm{F}_{1}$ 雑種のカプサイシノイド含量は，正逆交雑間で
差が見られた。“CW'と辛味品種との $\mathrm{F}_{1}$ 雑種では, 'CW'を種子親とした場合，カプサイシノイド含量が 多く，'CW'を花粉親とした場合に少なかった。一方， “伏見甘長'と “八房”との $F_{1}$ 雑種では逆の結果となり， 辛味のない品種である 伏見甘長”を花粉親とした方が カプサイシノイド含量が多かった．赤熟果では，未熟 果に比較して高濃度になる ‘しとう’や'Sinhong'と， 逆に低濃度になる'八房'，'Cheongyang'などの品種が あった。

果実の発育に伴うカプサイシノイド含最の変化を第 5 表に示した。いずれの品種でも，胎座のカプサイシ ノイド含量は，2３週間目から急激に增加し，4５ 週間目にピークに達し，その後徐々に減少した。し しとう'は，他の 2 品種と比較して急激な増加の始ま る時期がやや遅かった，果実の発育の㥞子を第 3 図に 示した、いずれの品種でも果実が坟大の生体重，最大 


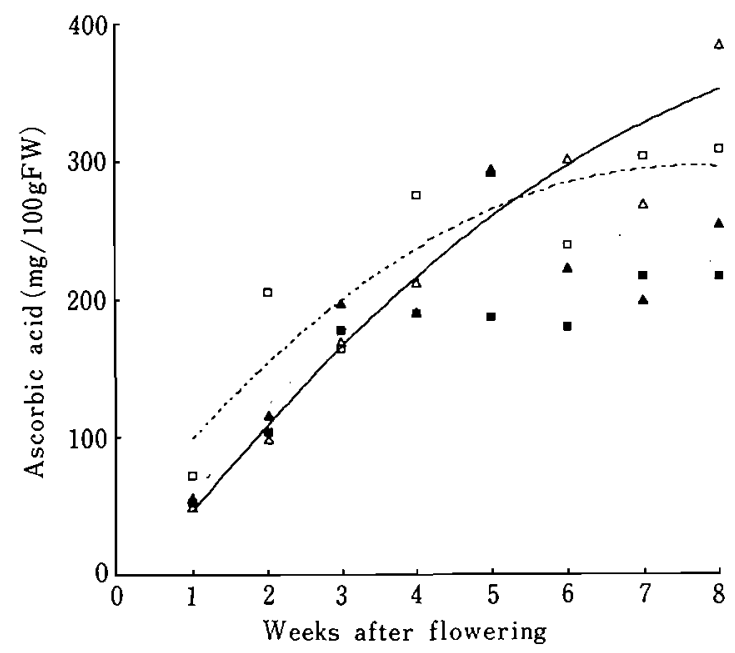

Fig. 1. Weekly changes in the ascorbic acid concentration in fruit flesh of 4 cultivars.

$$
\begin{aligned}
& \triangle \text {, 'Shishitou', } y=-3.2403 \mathrm{x}^{2}+72.806 \mathrm{x} \\
& -23.234 \\
& \mathrm{R}^{2}=0.9331 \\
& \square, \cdots \cdot \text {. 'Sinhong', } y=-4.4198 x^{2}+67.836 x+36.1 \\
& R^{2}=0.8072 \\
& \text { A. - 'Cheongyang', } y=-7.1214 \mathrm{x}^{2}+87.647 \mathrm{x} \\
& -22.128 \\
& \mathrm{R}^{2}=0.8075 \text {; } \\
& -5.5691 \\
& \mathrm{R}^{2}=0.9012 \text {; }
\end{aligned}
$$

の長さに達するのが5〜6週間目で, カプサイシノイ ド含量が最大となる時期とほぼ一致していた。

\section{考察}

本実験で，'CW’を片親にすることによって高収量 の $\mathrm{F}_{1}$ 雑種が得られ， $\mathrm{F}_{1}$ 雑種の No. 6, 7, 13 は, 1 植 物体当たり 37 日間で $1 \mathrm{~kg}$ を超える高収量であった。 その中でも No. 6 ('CW' × '伏見甘長”) は，高収量で アスコルビン酸含量が多く，カプサイシノイド含量が 少ないことから，辛味のない品種として有用な形質を もっていることが分かった。

篠原ら（1980）は，ピーマンの果実中のアスコルビ ン酸念量は, 植物体の令が進むにつれて増加したと報 告している. 本実験の結果では，果実のアスコルビン 酸含量はいずれの品種でも収穫開始時の7月下旬では 少なく，9月に最も高く，10月には低下した。このよ うに9月に最も高かったことについては，植物体の令 による影製と，温度などの栽培環境の影罄が考えられ る. 10 月にアスコルビン酸含量が低下したのは，温 度の低下が主な原因と考えられる，温度や日照などの

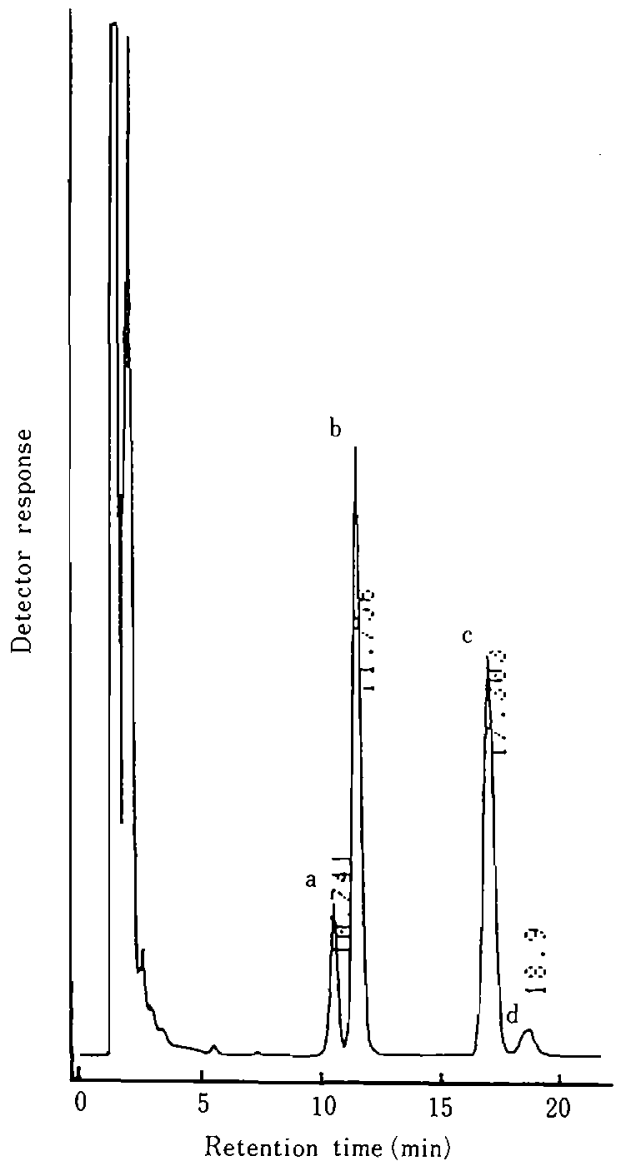

Fig. 2. HPLC chromatogram of capsaicinoids in Capsicum annum cv. 'Taka no Tsume' (a) nordihydrocapsaicin, (b) capsaicin, (c) dihydrocapsaicin, and (d) n-vanillyl-n-decanamide.

環境条件と植物体の令がどのように果実中のアスコル ビン酸含量に影響しているのかは，今後検討すべき問 題である.

本実験で得られたトウガラシ果実の発育に伴うアス コルビン酸含量の変化についての結果は，菅原 （1943）の報告しているビタミンC含量が果実の発育 に伴って增加するという結果とほぼ一致していたまま た，北川（1973）も，ピーマンおよびトマトのアスコ ルビン酸念量は未熟期に少なく，果実の発育に伴って 增加したことを報告している，菅原（1943）はイチゴ ・ナス・トウガラシを用いて覆いをした果実はビタミ ンC含量が著しく減少したことから，果実の肥大に伴 ってアスコルビン酸含量の増加する原因は果皮の光合 成によりアスコルビン酸が蓄積されることによると報 
Table 4. Content of capsaicinoids in immature and red mature fruits from August to September, 1995.

\begin{tabular}{|c|c|c|c|c|c|c|c|c|c|c|c|}
\hline \multirow{3}{*}{ Group } & \multirow{3}{*}{ No. Cultivar } & \multicolumn{9}{|c|}{ Content of capsaicinoids $(\mathrm{mg} / 100 \mathrm{~g} \mathrm{DW})^{z}$} & \multirow{3}{*}{ Total } \\
\hline & & \multicolumn{5}{|c|}{ Immature fruit } & \multicolumn{4}{|c|}{ Red mature fruit } & \\
\hline & & $\mathrm{NDHC}$ & C & $\mathrm{DHC}$ & VD & Total & $\mathrm{NDHC}$ & C & DHC & $V D$ & \\
\hline \multirow[t]{2}{*}{ Bell pepper } & 1. California Wonder & - - & - & - & - & - & - & - & - & - & - \\
\hline & & - & - & - & - & - & - & - & - & - & - \\
\hline \multirow[t]{9}{*}{ Japanese cultivar } & 2.Fushimi Amanaga & 1 & 1 & - & - & 2 & - & - & - & - & - \\
\hline & & - & - & - & - & - & - & - & - & - & - \\
\hline & 3.Shishitou & $1^{y}$ & 1 & 1 & - & 3 & 1 & 1 & 2 & - & 4 \\
\hline & & $10^{x}$ & 20 & 22 & 2 & 54 & 70 & 106 & 134 & 15 & 325 \\
\hline & 4. Yatsufusa & 23 & 200 & 189 & 10 & 422 & 2 & 5 & 6 & - & 13 \\
\hline & & 523 & 4574 & 4269 & 227 & 9593 & 240 & 709 & 904 & 66 & 1919 \\
\hline & 5. Taka no Tsume & 2 & 5 & 4 & 1 & 12 & 2 & 4 & 3 & 1 & 10 \\
\hline & & 173 & 576 & 498 & 31 & 1278 & 183 & 414 & 491 & 157 & 1245 \\
\hline & 우 $\hat{8}$ & & & & & & & & & & \\
\hline \multirow[t]{24}{*}{$F_{1}$ hybrid } & $6.1 \times 2$ & - & - & - & - & - & - & - & - & - & - \\
\hline & & - & 1 & 1 & - & 2 & - & - & - & - & - \\
\hline & $7.1 \times 3$ & - & - & 1 & - & 1 & - & - & - & - & - \\
\hline & & 23 & 147 & 122 & 4 & 296 & 16 & 49 & 51 & 10 & 126 \\
\hline & $8.1 \times 4$ & 1 & 2 & 2 & - & 5 & 1 & 3 & 2 & - & 6 \\
\hline & & 77 & 503 & 431 & 32 & 1043 & 81 & 507 & 443 & 54 & 1085 \\
\hline & $9.1 \times 5$ & - & 1 & 1 & - & 2 & - & 3 & 3 & - & 6 \\
\hline & & 36 & 405 & 312 & 15 & 768 & 80 & 774 & 702 & 48 & 1604 \\
\hline & 10. $2 \times 1$ & - & - & - & - & - & - & - & - & - & - \\
\hline & & - & - & 1 & - & 1 & - & 1 & - & - & 1 \\
\hline & $11.2 \times 3$ & - & - & - & - & - & - & 1 & - & - & 1 \\
\hline & & 2 & 3 & 5 & 1 & 11 & 6 & 7 & 10 & 1 & 24 \\
\hline & $12.2 \times 4$ & - & - & - & - & - & - & - & - & - & - \\
\hline & & 1 & 1 & 2 & - & 4 & 1 & 1 & 2 & - & 4 \\
\hline & $13.3 \times 1$ & 1 & 1 & - & - & 2 & - & - & - & - & - \\
\hline & & 4 & 19 & 17 & 1 & 41 & 4 & 19 & 18 & 2 & 43 \\
\hline & $14.3 \times 2$ & 1 & 1 & 1 & - & 3 & - & 1 & 1 & - & 2 \\
\hline & & - & - & - & - & - & - & 1 & - & - & 1 \\
\hline & $15.4 \times 1$ & - & 1 & - & - & 1 & - & - & - & - & - \\
\hline & & 9 & 54 & 47 & 4 & 114 & 15 & 118 & 92 & 9 & 234 \\
\hline & 16. $4 \times 2$ & - & 1 & - & - & 1 & - & 2 & 2 & - & 4 \\
\hline & & 4 & 15 & 13 & 1 & 33 & 63 & 177 & 191 & 13 & 444 \\
\hline & $17.5 \times 1$ & - & 1 & - & - & 1 & - & - & - & - & - \\
\hline & & 11 & 56 & 56 & 3 & 126 & 16 & 135 & 122 & 7 & 280 \\
\hline \multirow[t]{6}{*}{ Korean $F_{1}$ cultivar } & 18. Cheongyang & 2 & 19 & 8 & 2 & 31 & 2 & 22 & 13 & 1 & 38 \\
\hline & & 110 & 2080 & 878 & 51 & 3119 & 128 & 1302 & 806 & 45 & 2281 \\
\hline & 19. Sinhong & 2 & 9 & 4 & - & 15 & 2 & 30 & 14 & 1 & 47 \\
\hline & & 164 & 1169 & 724 & 58 & 2115 & 223 & 2913 & 1364 & 83 & 4583 \\
\hline & 20.Geoseong & 1 & 3 & 3 & - & 7 & 1 & 4 & 6 & 1 & 12 \\
\hline & & 68 & 388 & 580 & 20 & 1056 & 131 & 454 & 863 & 66 & 1514 \\
\hline
\end{tabular}

$\approx$ NDHC. C. DHC and VD mean nordihydrocapsaicin, capsaicin, dibydrocapsaicin and n-vanillyl-n-decanamide or isomer of dihydrocapsaicin, respectively.

* Upper row shows content in fruit flesh.

$x$ Lower row shows content in placenta.

* $\quad$ - means trace amount. 
Table 5. Weekly changes of capsaicinoid content in fruits, 1995.

\begin{tabular}{|c|c|c|c|c|c|c|c|c|c|c|}
\hline \multirow{3}{*}{$\begin{array}{l}\text { Weeks } \\
\text { after } \\
\text { flowering }\end{array}$} & \multicolumn{10}{|c|}{ Content of capsaicinoids $(\mathrm{mg} / 100 \mathrm{~g} \mathrm{DW})^{z}$} \\
\hline & \multicolumn{5}{|c|}{ Flesh } & \multicolumn{5}{|c|}{ Placenta } \\
\hline & NDHC & $\mathrm{C}$ & $\mathrm{DHC}$ & VD & Total & NDHC & $\mathrm{C}$ & $\mathrm{DHC}$ & VD & Total \\
\hline \multicolumn{11}{|c|}{ 'Shishitou' } \\
\hline 1 & - ж & 1 & - & - & 1 & - & 1. & - & - & 1 \\
\hline 2 & - & - & - & - & - & 2 & 3 & 1 & - & 6 \\
\hline 3 & - & 1 & - & - & 1 & 25 & 79 & 51 & 3 & 158 \\
\hline 4 & 1 & 2 & 1 & 1 & 4 & 32 & 105 & 80 & 3 & 220 \\
\hline 5 & 3 & 9 & 6 & 1 & 19 & 105 & 357 & 331 & 11 & 804 \\
\hline 6 & 2 & 6 & 6 & 2 & 16 & 101 & 378 & 323 & 14 & 816 \\
\hline 7 & 1 & 4 & 3 & - & 8 & 27 & 124 & 115 & 5 & 271 \\
\hline 8 & 1 & 2 & 1 & - & 4 & 16 & 58 & 60 & 2 & 136 \\
\hline \multicolumn{11}{|c|}{ 'Taka no Tsume' } \\
\hline 1 & - & 3 & - & - & 3 & 1 & 2 & 1 & - & 4 \\
\hline 2 & 2 & 6 & 3 & 1 & 12 & 86 & 212 & 126 & 46 & 470 \\
\hline 3 & 4 & 22 & 10 & 2 & 38 & 255 & 1358 & 790 & 144 & 2547 \\
\hline 4 & 6 & 33 & 22 & 2 & 63 & 311 & 2198 & 1428 & 119 & 4056 \\
\hline 5 & 4 & 31 & 23 & 2 & 60 & 275 & 2330 & 1643 & 110 & 4358 \\
\hline 6 & 5 & 27 & 21 & 2 & 55 & 338 & 1774 & 1629 & 128 & 3869 \\
\hline 7 & 4 & 18 & 18 & 1 & 41 & 313 & 1666 & 1670 & 88 & 3737 \\
\hline 8 & 5 & 19 & 20 & 3 & 47 & 269 & 986 & 1056 & 108 & 2419 \\
\hline \multicolumn{11}{|c|}{ 'Cheongyang' } \\
\hline 1 & - & 2 & 1 & - & 3 & 2 & 4 & 1 & - & 7 \\
\hline 2 & 4 & 8 & 3 & 1 & 16 & 175 & 550 & 227 & 41 & 993 \\
\hline 3 & 3 & 30 & 10 & 1 & 44 & 262 & 2620 & 934 & 83 & 3899 \\
\hline 4 & 3 & 23 & 9 & 2 & 37 & 135 & 2222 & 826 & 46 & 3229 \\
\hline 5 & 3 & 44 & 18 & 2 & 67 & 178 & 3112 & 1355 & 71 & 4716 \\
\hline 6 & 4 & 33 & 14 & 1 & 52 & 121 & 1648 & 725 & 41 & 2535 \\
\hline 7 & 1 & 17 & 8 & 1 & 27 & 55 & 979 & 483 & 26 & 1543 \\
\hline 8 & 2 & 36 & 16 & 1 & 55 & 94 & 1681 & 826 & 39 & 2640 \\
\hline
\end{tabular}

z NDHC, C, DHC and VD mean nordihydrocapsaicin, capsaicin. dihydrocapsaicin and n-vanillyl-n-decanamide or isomer of dihydrocapsaicin, respectively.

* - means trace amount.

告している．このことは，果実が赤くなるとアスコル ビン酸の蓄積速度は僬くなる本実験の結果と一致して いる，また，開花 4〜5週間目以降もアスコルビン酸 含蚚が堌加し続ける品種と，ほとんど增加しないかま たは減少する品種がみられたのは，果実の肥大が停止 し赤くなる時期の品種間での違いによるものと考えら れる。

トウガラシの果実品質についての重要な要因である カプサイシノイドの含量について，太田（1962）は, カプサイシンは果実の隔壁の表面より分泌され, 隔壁 と胎座に眝蔵されることを報告している，本実験の結 果でも，カプサイシノイド含器は果皮より胎座の力が 著しく多かった，そこで本研究では主として胎座のカ プサイシノイド含昔に注目することにした，本実験の 結果, C. annuum L.の辛味のない品種と辛味品種の交

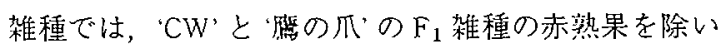
てほぼ両親の中間か，それより低濃度であった。朴・ 高橋（1980）はC. annuum L.の品種間交雑において, ほとんどの $\mathrm{F}_{1}$ のカプサイシノイド含量は両親の中間 的な值を示し，いくつかの組合せにおいてのみへテロ ーシスが認められることを報告している.太田 (1962)，朴・高橋（1980）は，トウガラシの辛味に関 する谓伝学的研究を行った結果, 甘味品種と辛味品種 の交雑では正逆交雑による差は認められなかったとし ている。しかし，本実験の結果，正逆交雑によりカプ サイシノイド含显に大きな差がみられ，CW'との交 雑では辛味品種を花粉親とした場合， $F_{1}$ 雑種のカプ サイシノイド含量が多く、伏見甘長”との交雑では辛 味品種を種子親とした場合 $\mathrm{F}_{1}$ 雑種のカプサイシノイ ド含念が多かった。この点についてはこれまで報告例 

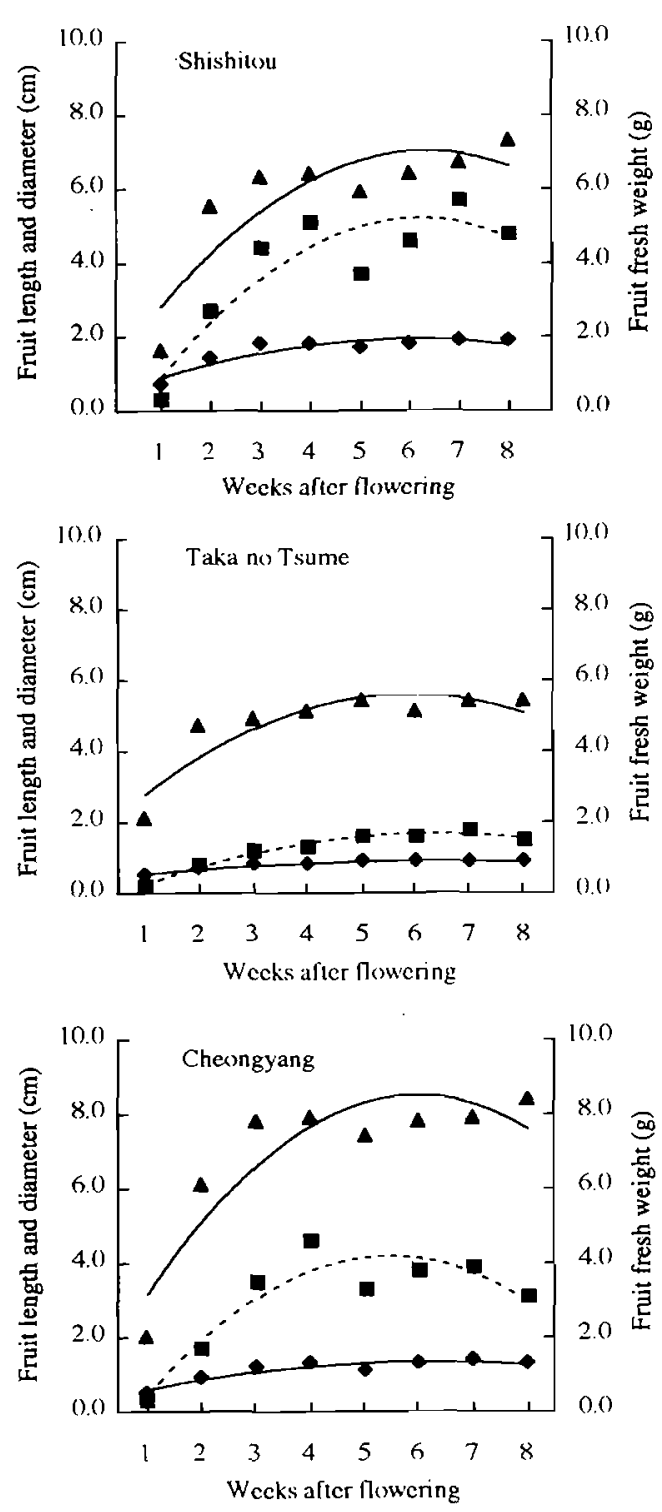

Fig. 3. Weekly changes in the fresh weight, length and diameter of fruits of three pepper cultivars.
A - Fruit lengh;
a. ….. Fruit fresh weight
$\rightarrow$. Fruit diameter.

がなく，令後の検討が必要である。

果実の発育に伴う力プサイシノイド含量の経時的変 化では，開花後約 1 週間目から蓄積さ水始力，果実が 最大のサイズに達する4ー5週間目に最高になった。 果実の肥大速度が最も大きいのはいずれの品種でも開 花後 1〜2週間であったが，カプサイシノイド含量の 增加が最も著しいのは品種によって多少暴なるがはぼ
開花後 2〜4週間であった。この結果からカプサイシ ノイドの蓄積は，果実がある程度肥大してからより盛 んになることが分かった。このように果実の生育と力 プサイシノイド含量は密接な関係がみられた，果実の 生育に伴うカプサイシノイド含量の経時的変化のパ夕 ーンの品種による違いは，果実の成熟速度の差晎によ るものと思われる。

本実験の結果得られた，トウガラシのアスコルビン 酸とカプサイシノイド含量の買伝様式，植物の生育環 境の影踾および果実発育に伴う経時的変化に関する知 見は，今後卜ウガラシの育種を進めていく上で大いに 役に立つと考えられる。

\section{摘 要}

高収量・高品質のトウガラシ新品種を生育する目的 で，日本在来種拐よび韓国の $\mathrm{F}_{1}$ 品種を供試し, 親品 種と比較しながら品種間雑種の収量, 果実のアスコル ビン酸含量怙よびカプサイシノイド含界を調查した。

1. 日本の固定種間の $\mathrm{F}_{1}$ 雑種はいずれも親品種より 高収量であり，特に‘カリフォルニア・ワンダー (CW)'を片漞とした場合，一果重が大きく果数も多 く，高収量であった。

2.アスコルビン酸は，胎座より果皮に多く含まれて いた，アスコルビン酸含量は, 品種間差異は少なく, 収莜時期による差が大きかった、いずれの品種でも， 9 月に最も含量が多かった。果実の発育に伴うアスコ ルビン酸含星の経時的変化を調べたところ，開花4一 5 週間後まではどの品種， $F_{1}$ 雑種も增加したが，そ の後も緩やかに増加する品種と, ほとんど増加しない かむしろ減少する品種があった。

3.カプサイシノイドは，果皮より胎座に高濃度で含 ま㣗ていた，胎座のカプサイシノイド含量は，“八房” などの辛味品種では $1000 \mathrm{mg} / 100 \mathrm{gDW}$ 以上で, 一方, 辛味のない品種の'CW'と伏見甘長'では，カプサイ シノイドはほとんど含まれていなかった。芉味のない 品種と罂味品種の $F_{1}$ 雑種のカプサイシノイド含量は, 正逆交雑により大きな差が見られた，果実の発育に伴 うカプサイシノイド含堅の経時的変化では，どの品種 でも開花 2 3 週間後に急激な増加が起こり，5週間 後で最大となり，その後は徐々に減少した。 カプサイ シノイド含量の最大となる時期は，果実の大きさが最 大となる時期とほぼ一致していた。

\section{引用文献}

Attuquayefio, V. K. and K. A. Buckle. 1987. Rapid sam- 
ple preparation method for HPLC analysis of capsaicinoids in capsicum fruits and oleoresins. J. Agric. Food Chem. 35:777-779.

Collins, M. D., L. M. Wasmund and P. W. Bosland. 1995.Improved method for quantifying capsaicinoids in Capsicum using high performance liquid chromatography. Hort Science 30: 137-139.

今堀䓔洋・茶珍和雄. 1995. ピーマン果実の成熟に伴 うアスコルビン酸代謝. 園学雑. 64 (別 1) : $562-563$.

北川雪恵. 1973. 果菜類の生育とビタミンCの分布 (II) トマト, ピーマン, イチゴ. 栄養と食糧. $26: 139-143$.

南出隆久. 1981。生理に関する実験. アスコルビン酸. p. 181-183. 大阪府立大学崖学部園芸学教室編.
園芸学実験・実習. 荃賢堂. 東京.

太田溙雄. 1962. トウガラシの辛味に関する生理学的 ならびに遺伝学的研究V. 辛味の遗伝. 遺伝学雑. $37: 169-175$.

朴 栽福・高橋基一。1980. トウガラシにおける辛味 成分のへテローシス表現と組合せ能力. 園学雑. 49:189-196.

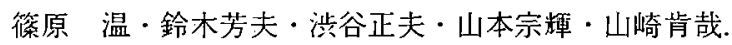
1980. トマト・ピーマンにおける施肥条件とアス コルビン酸含量について．園学雑. 49:85-92.

菅原友太. 1943. 果実, 塊茥, 根部の発育とビタミン

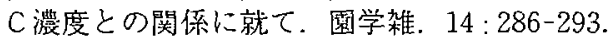

矢澤 進·上田昌弘・米留 昇・並木隆和. 1989 . 卜 ウガラシ属の種間雑種に㧍けるカプサイジイド 生成. 園学䧱. $58: 353-360$. 